\title{
PENINGKATAN DIGITAL IMAGE PROCESSING DALAM MENDESKRIPSIKAN TUMBUHAN JAMUR DENGAN SEGMENTASI WARNA, DETEKSI TEPI DAN KONTUR
}

\author{
Sofika Enggari ${ }^{1}$, Agung ramadhanu ${ }^{2}$,Hari marfalino ${ }^{3}$ \\ ${ }^{123}$ Fakultas Ilmu Komputer, Universitas Putra Indonesia "YPTK” Padang, Jl Lubuk Begalung Padang \\ email: sofika_enggari@upiyptk.ac.id
}

\begin{abstract}
Jamur merupakan tumbuhan yang dapat dikonsumsi oleh manusia sebagai makanan. Jamur seperti tubuh buah yang tampak di permukaan media tumbuh dari sekelompok fungi (Basidiomycota) yang berbentuk seperti payung. Beberapa jamur aman dimakan manusia bahkan beberapa jamur dianggap sebagai obat dan ada beberapa yang lain beracun. Sampai pada saat ini masih ada kita dengar berita mengenai keracunan makanan dari jamur ini. Sehingga ada beberapa kejadian yang berakibat fatal yaitu berupa kematian. Untuk mengurangi atau menghilangkan keracunan dari makanan jamur ini peneliti mencoba melakukan penelitian terhadap jamur ini dengan memberikan solusi berupa digital image processing dalam mendeskripsikan tumbuhan jamur dengan segmentasi warna, deteksi tepi dan kontur, terhadap jamur yang boleh dikonsumsi dan yang tidak dikomsumsi melalui proses penerepan BPNN (Back Propagation Neural Network). Metode jaringan saraf tiruan ini terbukti mampu merepresentasikan input dari contoh-contoh citra yang diberikan sehingga dapat melatih jaringan hingga diperoleh bobot yang diinginkan dengan hasil akurasi sebesar $80 \%$. Sehingga dengan adanya sistem digital image processing ini dapat membantu masyarakat dalam menentukan jamur yang dapat dikonsumsi dan yang tidak dapat dikonsumsi.
\end{abstract}

Keywords: Jamur, Image Processing, BPNN

\section{PENDAHULUAN}

Jamur atau cendawan adalah tum buhan yang tidak mempunyai klorofil sehingga bersifat heterotrof. ${ }^{[1]}$ Jamur ada yang uniseluler dan multiseluler. ${ }^{[1]}$ Tubu hnya terdiri dari benang-benang yang disebut hifa, Hifa dapat membentuk anyaman bercabang-cabang yang disebut miselium. Reproduksi jamur, ada yang dengan cara vegetatif ada juga dengan cara generatif. Jamur menyerap zat organik dari lingkungan melalui hifa dan miseliumnya untuk memperoleh makanannya. Setelah itu, menyimpannya dalam bentuk glikogen. Jamur merupakan konsumen, maka dari itu jamur bergantung pada substrat yang menyediakan karbohidrat, protein, vitami $\mathrm{n}$, dan senyawa kimia lainnya. Semua zat itu diperoleh dari lingkungannya. Sebagai makhluk heterotrof, jamur dapat bersifat parasit obligat, parasit fakultatif, atau saprofit.

Beberapa jamur aman dimakan manusia bahkan beberapa dianggap berkhasiat obat, dan beberapa yang lain beracun. Contoh jamur yang bisa dimakan: jamur merang (Volvariela volvacea), jamur tiram (Pleurotus), jamur kuping (Auricularia polytricha), jamur kancing atau champignon (Agaricus campestris), dan jamur shiitake (Lentinus edulis).

Ada berbagai macam jenis jamur yang tersebar diseluruh dunia, diantara nya menjadi penyebab penyakit pada manusia dan tanaman, bahkan mengandung racun (Parjimo et al. 2007).

Keanekaragaman jamur didunia terdapat lebih dari 1.500 .000 jenis dan hanya sekitar 74.000 yang sudah dikenali (Hawksworth, 2001). Jenis jamur yang sudah dikenali tersebut juga bermanfaat dalam bidang pangan, kesehatan, ekonomi, pertanian dan ada pula yang 
dapat menyebabkan infeksi pada manusia (Tyasrini, 2006). Faktor ini menyebabkan pengenalan terhadap jamur sangat penting dimana dapat membedakan jenis yang bisa digunakan manusia dengan yang tidak.

Karakteristik tertentu juga hanya dimiliki tanaman ini, seperti ukuran, warna, serta bentuk dari tudung dan tangkai merupakan ciri penting dalam melakukan identifikasi suatu jenis jamur (Smith et al. 1988). Identifikasi sangat penting karena pencarian kembali jenis tanaman di dalam penyimpanan data jenis tanaman sangat sulit dan memerlukan waktu yang lama (Murdoko et al. 2015). Proses identifikasi tersebut juga disertai dengan klasifikasi, dimana setiap jenis tanaman dapat ditentukan sesuai dengan nama tanaman sebenarnya (Ardiansjah, 2012).

Penelitian terhadap tanaman jamur sebelumnya telah dilakukan (Simon, 2013) menerapkan deteksi jamur dengan mobile device menggunakan metode Support Vector Machine (SVM) dan menggabungkan beberapa ekstrasi fitur seperti fitur histogram serta fitur bentuk. Selanjutnya dilakukan penelitian oleh (Sinaga, 2014) dengan melakukan pengenalan pertumbuhan jamur menggunakan metode jaringan saraf tiruan Learning Vector Quantization (LVQ) dimana citra yang digunakan adalah citra jamur tiram. Metode jaringan saraf tiruan ini terbukti mampu merepresentasikan input dari contohcontoh citra yang diberikan sehingga dapat melatih jaringan hingga diperoleh bobot yang diinginkan dengan hasil akurasi sebesar $80 \%$.

Seiring dengan kemajuan teknologi komputer, penggunaan computer vision untuk pembelajaran menganalisis gambar atau video untuk mendapatkan hasil sebagaimana yang bias dilakukan manusia serta pada hakikatnya, computer vision mencoba meniru cara kerja sistem visual manusia (Human vision). Dari permasalahan diatas, maka peneliti berkeinginan untuk melanjutkan penelitian ini agar mendapatkan akurasi dan hasil deskripsi yang tepat dan cepat mengenai tumbuhan jamur ini dengan melakukan peningkatan terhadap digital images processing dalam segi deteksi warna, deteksi tepi dan kontur untuk mendeskripsinya, terhadap jamur yang boleh dikonsumsi dan yang tidak dikomsumsi melalui proses penerepan BPNN (Back Propagation Neural Network).

Segmentasi warna merupakan proses segmentasi dengan pendekatan daerah yang bekerja dengan menganalisis nilai warna dari tiap piksel pada citra dan membagi citra tersebut sesuai dengan fitur yang diinginkan. Segmentasi citra dengan deteksi warna HSV menurut Gunanto (2009) menggunakan dasar seleksi warna pada model warna HSV dengan nilai toleransi tertentu. Pada metode segmentasi dengan deteksi warna HSV menurut Giannakupoulos (2008), dilakukan pemilihan sampel piksel sebagai acuan warna untuk membentuk segmen yang diinginkan. Citra digital menggunakan model warna RGB sebagai standar acuan warna, oleh karena itu proses awal pada metode ini memerlukan konversi model warna RGB ke HSV. Untuk membentuk segmen sesuai dengan warna yang diinginkan maka ditentukan nilai toleransi pada setiap dimensi warna HSV, kemudian nilai toleransi tersebut digunakan dalam perhitungan proses adaptive threshold. Hasil dari proses threshold tersebut akan membentuk segmen area dengan warna sesuai toleransi yang diinginkan. Secara garis besar, gambaran proses segmetnasi dapat dilihat pada Gambar 1 dan berikut ini merupakan proses segmentasi menurut Giannakupoulos (2008).

Pendeteksian tepi akan menghasilkan citra tepi yang berupa citra biner (pixel tepi berwarna putih, sedangkan pixel bukan tepi berwarna hitam). Tetapi, tepi belum memberikan informasi yang berguna karena belum terdapat keterkaitan antara suatu tepi 
dengan tepi lainya. Citra tepi ini harus diproses lebih lanjut untuk menghasilkan informasi yang lebih berguna yang dapat digunakan dalam mendeteksi bentukbentuk yang sederhana (misalnya garis lurus, lingkaran, elips, dan sebagainya) pada proses analisis citra. Rangkaian dari pixel-pixel tepi yang membentuk batas daerah (region boundary) disebut kontur (Contour).

\section{METODE PENELITIAN}

Kerangka kerja yang ada pada penelitian ini dapat dilihat pada Gambar 4.1 :

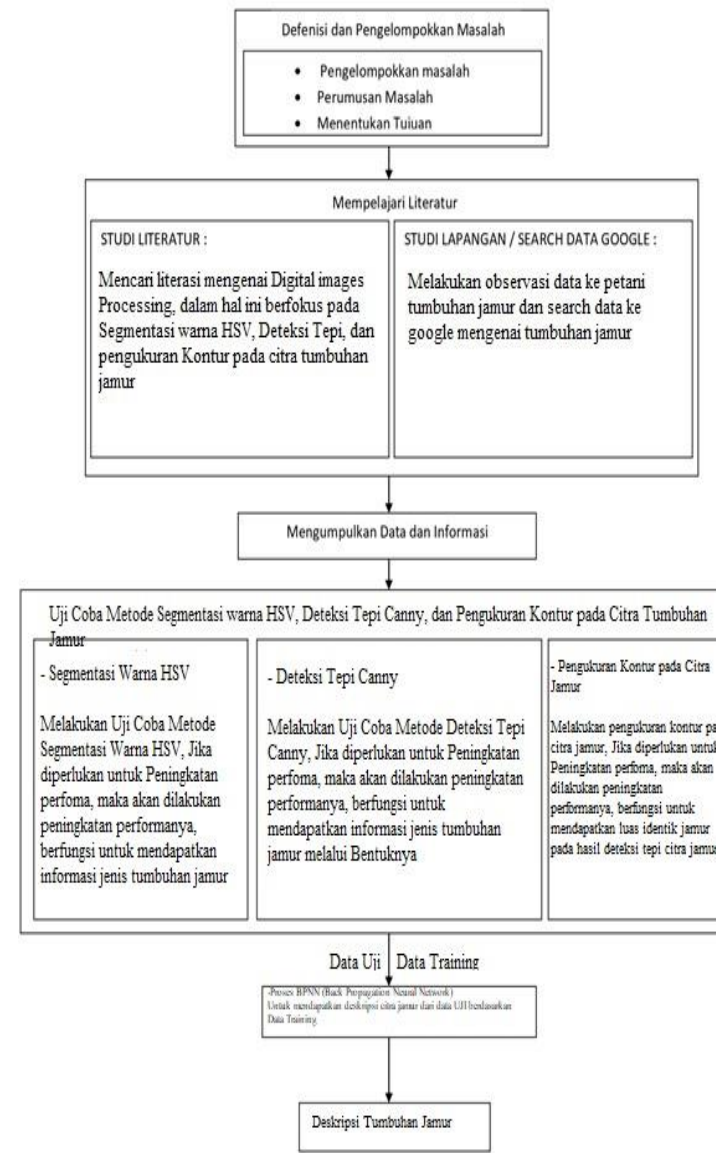

\section{Gambar 4.1 Kerangka Kerja Dalam Penelitian}

Dari kerangka kerja yang digambarkan diatas maka dapat diuraikan pembahasan masing-masing kegiatan sebagai berikut ini:
1. Defenisi
dan Pengelompokkan

Masalah

a. Pengelompokkan Masalah
Hal Utama yang harus ditentukan pada segmentasi defenisi dan pengelompokkan masalah adalah terletak pada saat peneliti hendak melakukan pemilihan dan pengelompokkan masalah yang akan diteliti, karena dengan hal tersebut dapat membantu peneliti untuk fokus dan memudahkan peneliti terhadap masalah apa yang hendak akan di selesaikan atau create solution.

b. Perumusan Masalah

Setelah peneliti melakukan pengelompokkan masalah, maka yang harus dikerjakan selanjutnya adalah melakukan perumusan masalah tersebut dengan cara memasukkanya ke dalam tabel kluster permasalahan, sehingga terciptalah beberapa item-item inti masalah yang akan dibentuk menjadi perumusan masalah.

c. Menentuan Tujuan

Berdasarkan perumusan masalah dan hipotesa yang telah dibuat pada tahap sebelumnya, maka tahap penentuan tujuan berguna untuk memperjelas kerangka tentang apa saja yang menjadi sasaran dari penelitian ini.

2. Mempelajari Literatur

Dalam mempelajari studi literatur ada dua tahap dilakukan yaitu :

a. Melakukan Studi Literatur, dengan mencari literasiliterasi informasi mengenai tumbuhan jamur.

b. Melakukan Studi Lapangan / Search Data Google Studi lapangan / Search Data Google yang penulis lakukan pada objek yang diteliti dengan cara :

a. Observasi dan Wawancara, yaitu melakukan tanya jawab langsung dengan salah seorang Subjek penelitian yang 
bertanggung jawab terhadap pengelolaan Objek Penelitian.

b. Searching Informasi dan Rating Objek Penelitian, hal ini adalah daya dan upaya peneliti untuk mendapatkan Resource Informasi yang dapat diolah sebagai bahan penelitian ini agar lebih real dan kompleks terhadap tumbuhan jamur.

3. Mengumpulkan dan Menganalisa Data

Proses pengumpulan dan analisa data dilakukan bersama tim peneliti dan bagian-bagian yang terkait dengan berjalannya dan lancarnya penelitian ini.

4. Menganalisa Sistem dan Create Solution

Dalam analisa data ada beberapa tahapan yang dilakukan yaitu :

1. Segmentasi Warna HSV

Melakukan Uji coba metode segmentasi warna HSV untuk mendapatkan deskripsi dari citra jamur melalui warna jamur, jika diperlukan peningkatan perfoma metode, akan maka peneliti akan melakukan peningkatan.

2. Deteksi Tepi Canny

Melakukan Uji coba metode deteksi tepi canny untuk mendapatkan bentuk tepi dari citra jamur, jika diperlukan peningkatan perfoma metode, akan maka peneliti akan melakukan peningkatan.

3. Pengukuran Kontur Melakukan pengukuran kontur terhadap luas bentuk tumbuhan jamur pada citra jamur.
Melakukan pengujian terhadap data training dan data uji, agar menghasilkan keakurasian deskripsi tumbuhan jamur pada citra jamur.

6. Deskripsi Tumbuhan Jamur Mendapatkan informasi akurat seputar deskripsi tumbuhan jamur yang boleh dikonsumsi dan yang tidak boleh dikonsumsi.

\section{HASIL DAN PEMBAHASAN}

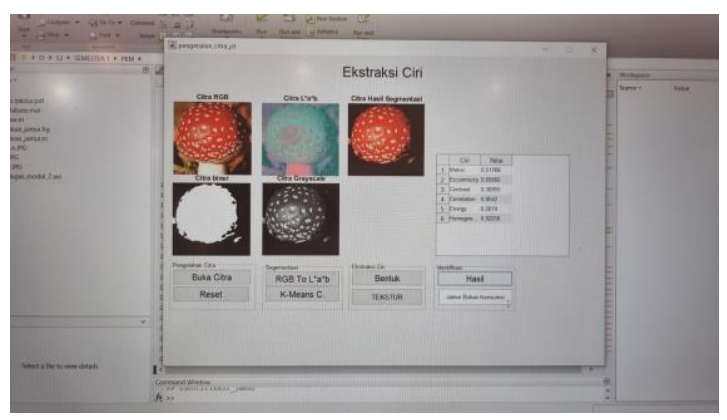

Gambar1. Gambaran aplikasi

\section{SIMPULAN}

Dari permasalahan yang dihadapi oleh usaha mikroini, maka saya mencoba untuk memberikan solusi agar semua masalah tersebut dapat diselesaikan dengan baik. Adapun solusi yang saya ajukan antara lain :

1. Memberikan pelatihan dari implementasi hasil penelitian kepada para petani didalam proses deksripsi jamur menggunakan image processing.

2. Membangun sebuah sistem didalam proses deskripsi jamur sehingga dapat meningkatkan keakuratan hasil deskripsi jamur.

3. Memberikan sosialisasi kepada para petani jamur untuk penggunaan teknologi sehingga dapat melakukan pekerjaan dengan mudah.

5. Proses BPNN (Back Propagatio Neural Network) 


\section{DAFTAR PUSTAKA}

Hawksworth DL (1991). The fungal dimension of biodiversity: magnitude, significance, and conservation. Mycological Research 95: 641-655.

Hawksworth DL (1992). The need for a more effective biological nomenclature for the 21st century. Botanical Journal of the Linnean Society 109: 543-567.

Hawksworth DL (2001). The magnitude of fungal diversity: the 1.5 million species estimate revisited. Mycological Research 105: 14221432.

Hawksworth

DL (2004a)

'Misidentifications' in fungal DNA sequence databanks. New Phytologist 161: 13-15.

Hawksworth DL (2004b). Biological papers without cited voucher material are so much waste paper. European Science Editing 30: 81-83.

Hawksworth DL, Kirk PM, Sutton BC, Pegler DM (1995). Ainsworth \& Bisby's dictionary of the fungi. 8th edition. $\mathrm{CAB}$ International, Wallingford.

Hawksworth DL, Rossman AY (1997). Where are all the undescribed fungi? Phytopathology 87: 888-891.

Tyasrini, E., Winata, T. \& Susantina. 2006. Hubungan antara sifat dan metabolit Candida spp. dengan patogenesis kandidiasis. Jurnal Kedokteran Maranatha, Vol. 6, No.1. [Online]. Available from http://majour.maranatha.edu/index.ph p/jurnal-kedokteran/article/view/86 [Accessed 19 Maret 2014]

Smith LM, et al. (1988) Identification and characterization of mutations affecting sporulation in Saccharomyces cerevisiae. Genetics 120(4):899-907
Ardi Murdoko Sudarmadji dan Lana Sularto, 2007. "Pengaruh Ukuran Perusahaan, Profitabilitas, leverage, dan Tipe Kepemilikan Perusahaan Terhadap Luas Voluntary Disclosure Laporan Keuangan Tahunan", Proceeding PESAT, Volume 2.

Ardiansyah, M. 2012. Medikal Bedah Untuk Mahasiswa. Jogjakarta: Diva Press Departemen Kesehatan Republik Indonesia. 2005. Standar Profesi Fisioterapi di Rumah Sakit Departemen Kesehatan RI. Pedoman Penanggulangan Tuberkulosis (TB): Jakarta. 2009

Departemen Kesehatan Republik Indonesia. 2005. Standar Profesi Fisioterapi di Rumah Sakit

Departemen Kesehatan RI. Pedoman Penanggulangan Tuberkulosis (TB): Jakarta. 2009

Aminin, A. L. N., D. H. Sinaga dan L. Suyati. 2014. Studi Pendahuluan Pemanfaatan Whey Tahu sebagai Substrat dan Efek Luas Permukaan Elektroda dalam Sistem Mircobial Fuel Cell. Jurnal Sains dan Matematika 22 (2): 30-35.

Cappuccino, J. G. and N. Sherman. 2005. Microbiology: a Laboratory Manual. 7th Ed. Pearson Education, Inc. Publishing as Benjamin Cummings. San Francisco.

CA. Chadhuri, S. K. and D. R. Lovley. 2003. Electricity generation by direct oxidation of glucose in mediatorless microbial fuel cell. Nat Biotechnol 21: 1229-1232.

Castleman K.R. (1996). Digital image processing. Prentice Hall, New Jersey.

Forsyth, D.A., Ponce, J. (2003). Computer vision: A modern approach. Prentice Hall, New Jersey.

Giannakopoulos, T. (2008). Matlab color detection software, Department of 
DOI : https://doi.org/10.47233/jteksis.v4i1.358

Informatics and Telecommunications, University of Athens, Greece. Diambil dari http://www.di.uoa.gr/ tyiannak

Gonzalez, Rafael C., Woods, Richard E. (2001). Digital image processing. Prentice Hall, New Jersey.

Gunanto, S.G. (2009). Segmentasi warna bagian tubuh manusia pada citra 2D. Proceeding SENTIA.

Perales, F. (2002). Human motion analysis \& synthesis using computer vision and graphics techniques, State of Art and Applications, Report on Computer Graphics and Vision Group, Department of Computer Science-Universitat deles Illes Balears (UIB), Perancis

Rujikietgumjorn, S. (2008). Segmentation methods for multiple body parts, Project in lieu of Thesis, University of Tennessee, Knoxville. 